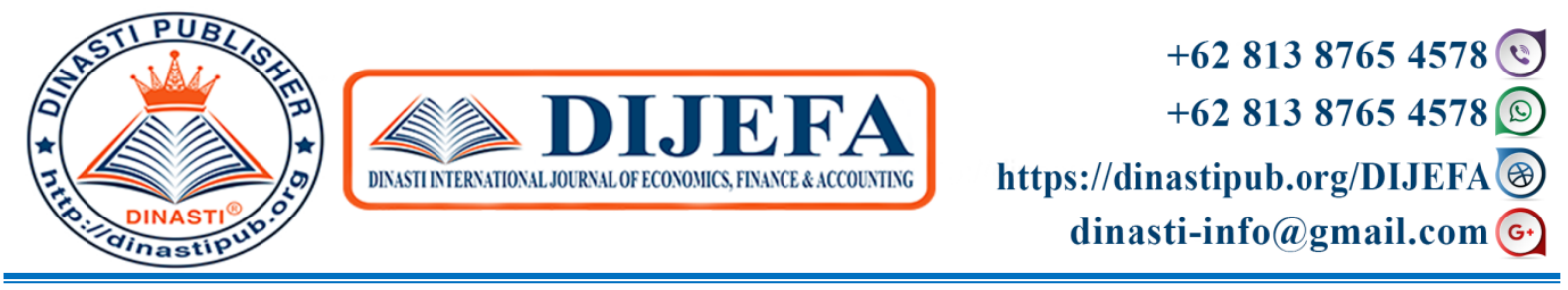

\title{
ANALYSIS OF EXPORT COMPETITIVENESS TEXTILE AND APPAREL INDONESIA, CHINA, INDIA
}

\author{
Bambang Susanto ${ }^{1}$, Sukadwilinda ${ }^{2}$ \\ ${ }^{1)}$ Universitas Sangga Buana YPKP, Bandung, Indonesia \\ 2) Universitas Sangga Buana YPKP, Bandung, Indonesia
}

\begin{tabular}{|c|c|}
\hline $\begin{array}{l}\text { ARTICLE INFORMATION } \\
\text { Received: 16 March } 2020 \\
\text { Revised: 22 March } 2020 \\
\text { Issued: } 27 \text { March } 2020 \\
\text { Corresponding author: } \\
\text { Bambang Susanto } \\
\text { E-mail: } \\
\text { bambang.susanto@usbypkp.ic.id } \\
\text { bambang.susanto18@gmail.com }\end{array}$ & $\begin{array}{l}\text { Abstract: The textile and apparel industries are labor- } \\
\text { intensive and capital-intensive industries. The focus of } \\
\text { this research looks at the competitiveness of textiles } \\
\text { and apparel in Indonesia, China and India. The } \\
\text { research method used is comparative descriptive, with } \\
\text { the Herfindahl approach, Trade Specialization, } \\
\text { Relevealed Comparative Adventage and Constan } \\
\text { Market Share. Herfindahl calculation shows the } \\
\text { market structure in Indonesia, China and India in the } \\
\text { form of perfect competition. While the Trade } \\
\text { Specialization approach, Indian exports are more } \\
\text { stable than Indonesia and China. The TSR approach } \\
\text { generally shows Export Promotion. The Revealed } \\
\text { Comparative Adventage approach, Indonesia and India } \\
\text { show stable and stagnant results, the RCA scale shows } \\
\text { that China has a comparative advantage and strong } \\
\text { competitiveness. Conclusion of the research, the } \\
\text { market structure takes the form of a perfect } \\
\text { competition and Export Promotion. China Has } \\
\text { comparative advantages and strong competitiveness, } \\
\text { followed by Indonesia and India. } \\
\text { Keywords: Competitiveness, Herfindahl, TSR, RCA, } \\
\text { CMS }\end{array}$ \\
\hline
\end{tabular}

\section{INTRODUCTION}

Indonesia, China, India are three countries with the population the top 5 in the world. Such a large population is a demographic bonus and at the same time a high social burden. China has a population of $1,379,302,771$ people, with a ratio of $18.6 \%$ of the world's population $(7,405,107,650$ people: CIA World Factbook 2017). India has a population of $1,281,935,911$ people $(17.3 \%)$, Indonesia $260,580,735$ people $(3.5 \%)$. The large population is a strategic world market for other countries. A country with a large population is a force for industry in a country that prefers labor-intensive industries (Nordås \& Geneva, n.d.). The textile and apparel industry is a combination of capital and labor intensive industries. The 
world community and industry whose population is more than 7 billion people, are very dependent and in need of textiles and apparel.

Indonesia's exports of textiles and clothing are spread in 188 countries in the world (WITS 2017) with the largest export destinations to the United States, Japan, China, Turkey, the Republic of Korea. Whereas China's export destinations are spread over 209 countries, with the largest destinations being the United States, Japan, Hong Kong, Vietnam and the United Kingdom. While the destination of exports of Indian textiles to 203 countries: America, Bangladesh, the United Arab Emirates, Britain and Germany. The main purpose of the three countries producing textile and apparel in the world is to America and Germany. Although China is an exporter of textiles and apparel to more than 209 countries, the Chinese market is flooded with textiles and apparel from Indonesia. The data for textile export and manufactured export are collected from UN COMTRADE Statistics from World Integrated Trade Solution (WITS) provided by World Bank (Alam, 2018)

The strength of the Chinese economy is seen from the total export number of $2,263,370,504.30$ in thousands of US $\$$ and total imports $1,843,792,938.80$ in thousands of US $\$$, this can be called the Chinese trade balance leading to a positive trade balance $419,577,565.51$ in thousands of US \$ Trade growth of $2.43 \%$ compared to world growth of $1.50 \%$ (WITS). While India had a total export of $294,364,490.16$ in thousands of US $\$$ and total imports of 444,052,353.84 in thousands of US \$, until the end of 2017 the Indian trade balance was negative $(149,687,863.67)$ in thousands of US $\$$. India's trade growth was $1.10 \%$ compared with world growth of $1.50 \%$. While Indonesia has total exports of $168,810,042.93$ in thousands of US \$ and total imports of 157,388,168.47 in thousands of US $\$$, leading to a positive trade balance of $11,421,874.46$ in thousands of US \$. Indonesia's trade growth was $2.21 \%$ compared with world growth of $1.50 \%$.

The competitiveness of the textile industry and apparel to a country can be seen from Revealed Comparative Adventange, (Jayawickrama \& Thangavelu, 2010) a method that measures the export performance of a particular commodity in the total exports of a country. If the RCA value is greater than 1 then a country can be said to have a comparative advantage in commodities and strong competitiveness and or vice versa. Meanwhile, to measure the market structure and market share Herfindahl Index analysis is used, (Mcauliffe, 2014) If the Herfindahl Index approaches 0, the market structure shows perfect competition, whereas if more than 1 market structure is Monopolistic. The Constant Market share approach (Amador $\&$ Cabral, 2008) illustrates the effect of world growth, commodity effects, market effects and the effect of competitiveness on the observed changes in a country's exports. The final result of the CMS is obtaining an equation that illustrates the effect of world growth, Commodity effect, Market effect, and Competitive effect on the observed changes in a country's exports.

\section{LITERATURE REVIEW}

The textile and apparel sector is one of the most important economic sectors in the world. Many studies predict that India will get a significant share of the world textile and apparel trade because of the advantages of cheap labor and other resource factors (Kathuria, 2013).(Kathuria, 2013) analyzes the comparative advantage of India and Bangladesh for the world export trade in the apparel sector with the help of the Balassa index, Revealed Comparative Advantage. His research results show India has a comparative advantage up 
from 23 to 34 products while Bangladesh from 21 to 34 products. (Kilduff \& Chi, 2007). (Guan et al., 2019) analyze raw materials, labor, capital, demand, related industries, strategies and policies that affect the international competitiveness of China's textile and apparel industry. Analysis was performed using the "Diamond Model", where raw materials, labor, capital, demand, related industries, strategies and policies were included as explanatory variables, and the impact of international competitiveness on market share (MS), trade competitiveness (TC) and comparative advantage (RCA) Research findings imply that it is necessary to increase investment in the fixed assets of the Chinese textile and apparel industry, accelerate the pace of equipment upgrading, increase the rate of industrialization, while strengthening the supply of textile raw materials, and reduce raw material prices, thereby reducing company costs textiles and apparel. (Jayawickrama \& Thangavelu, 2010) Test trade relations and the level of export competitiveness between Singapore, China and India. The Balassa export performance index and dynamic RCA index were adopted to identify revealed comparative advantages (RCA) from Singapore, China and India in industrial products with 1 and 2 digit SITC levels. (Jayawickrama \& Thangavelu, 2010) found that exports of Singapore and China complement each other, even though the level of complementarity has declined over time. Meanwhile, Singapore and India exports were found to be a stronger and more stable complement.

\section{RESEARCH METHODS}

The research method used is comparative descriptive (Lieberman, 2005), by making comparisons of textile products and apparel into three sample countries (Indonesia, India and China) with the Herfindahl Index, Trade Specialization Ratio, Relevealed Comparative Adventage and Constan Market Share approaches. Research period for eight years (20102017). Data sourced from the World Integrated trade solution (WITS). The final results of this study provide an overview of: Comparative Advantages and Competitiveness, (Maryam et al., 2018). Balassa's competitiveness indicators are ex-post concepts (Balassa, 1965; Suwannarat, 2017). Many studies have determined a country's competitiveness via the paradigm of Balassa by comparing commodity share in its exports to the commodity share in world exports, referred to as its revealed comparative advantage (RCA) (Balassa, 1965; Seyoum, 2007; Huo, 2014;Suwannarat, 2017). If the RCA is greater than 1, it is taken as evidence of international competitiveness. It compares how well a country has done in export of some particular set of goods. Balassa (1967;Suwannarat, 2017) claims that comparative advantage is revealed by observed trade patterns, i.e. high shares of export markets. RCA is grounded in conventional trade theory and measures a country's exports of a commodity relative to that of a set of countries (Seyoum, 2007; Suwannarat, 2017)

\section{A. Herfindahl index}

Herfindahl Index (Mahajan, 2019): measures the size of companies in an industry group and as an indicator of the amount of competition among existing industries. Herfindahl Index value reflects the value of market share control by a company in an industry.

$$
\begin{aligned}
& \mathrm{HI}=\operatorname{sij} 12+\operatorname{sij} 22+\operatorname{sij} 32+\ldots+\operatorname{sijn} 2 \\
& \text { Where: } \\
& \mathrm{HI}=\text { Herfindahl Index } \\
& \text { si = Country market share in the world trade in Textile \& apparel commodities }
\end{aligned}
$$


$\mathrm{n}=$ Number of countries involved in world trade in Textile $\&$ apparel commodities

\section{B. Trade Specialization Ratio (TSR)}

This method recognizes changes or shifts in comparative advantage for each product, which is developing and going down.

$\mathrm{TSR}=\mathrm{E}(\mathrm{ij})-\mathrm{M}(\mathrm{ij}) \mathrm{E}(\mathrm{ij})+\mathrm{M}(\mathrm{ij})$

Where :

$E(i j)=$ Export value of commodity i from each country j every year

$\mathrm{M}(\mathrm{ij})=$ Import value of commodity $\mathrm{i}$ from each country $\mathrm{j}$ every year

TSR Method Stages:

1. Introduction stage, the TSR rate ranges from -1 to -0.5 .

2. Stages of Import Substitution, the TSR rate ranges from -0.5 to 0

3. Stages of Export Expansion, TSR figures range from 0 to 0.8

4. Adult / maturation stage, TSR rate is around +0.8

\section{Revealed Comparative Advantage}

(Maryam et al., 2018) RCA, a method of measuring the performance of certain commodity exports in the total exports of a country compared to the market share of these commodities with world trade.

$$
\mathrm{RCA}=\frac{\mathrm{X}_{\mathrm{j}}^{\mathrm{A}} / \mathrm{X}^{\mathrm{A}}}{\mathrm{X}_{\mathrm{j}}^{\mathrm{W}} / \mathrm{X}^{\mathrm{W}}}
$$

The RCA formula is as follows:

Where :

RCA $=$ Revealed Comparative Advantage

$X_{j}^{A}=$ Country A's export value for commodities $\mathrm{j}$

$X^{A}=$ Value of total exports of country A

$X_{j}^{W}=$ World export value for commodities $\mathrm{j}$

$X^{W}=$ Value of total world exports

If the RCA value is greater than 1 , it can be said that the country has a comparative advantage in related products and is highly competitive. If an RCA value of less than 1 indicates weak competitiveness (Saki et al., 2019)

\section{Constant Market Share}

The CMS method is based on the understanding that a country's export growth rate can be lower or higher than the world export growth rate (Amador \& Cabral, 2008). A country's export growth can be described in three effects, namely the effect of commodity composition, the effect of market distribution, the effect of competitiveness. The three effects are then entered into one equation:

$$
\begin{gathered}
s=\frac{q}{Q} \\
\mathrm{q}=\mathrm{s} . \mathrm{Q} \\
\frac{d q}{d t}=\frac{u^{\prime} V-V^{\prime} u}{V^{2}}=0
\end{gathered}
$$




$$
\begin{gathered}
\dot{q}=\frac{d s}{d t} \cdot Q+s \cdot \frac{d Q}{d t} \\
\dot{q}=\dot{s} Q+s \dot{Q}
\end{gathered}
$$

Where :

$\mathrm{S}=$ Market Share; $\mathrm{q}=$ Country; $\mathrm{Q}=$ world $; \mathrm{q}^{*}=\mathrm{CMS} ; \mathrm{sQ}^{*}=$ Growth Effect;

$\mathrm{s}^{\mathrm{Q}} \mathrm{Q}=$ Competitiveness Effect

If the result of $\mathrm{q}^{\cdot}$ is positive it indicates an increase in world growth and an increase in competitiveness that contributes to an increase in a country's growth. The result of negative $q$ menunjukkan shows a decrease in world growth and a decrease in competitiveness that contributes to the decline in a country's exports.

\section{RESULTS AND DISCUSSION}

Table.1 Herfindahl Indek (Indonesia, China, India)

\begin{tabular}{ccccc}
\hline Year & $\begin{array}{c}\text { Indonesian } \\
\text { Textile and } \\
\text { Apparel Exports }\end{array}$ & $\begin{array}{c}\text { Chinese Textile } \\
\text { and Apparel } \\
\text { Exports }\end{array}$ & $\begin{array}{c}\text { Textile and Apparel } \\
\text { Exports }\end{array}$ & $\begin{array}{c}\text { World } \\
\text { Textile } \\
\text { Exports }\end{array}$ \\
\hline 2010 & 0,154017954 & 0,053452056 & 0.060347925 & 0.081006411 \\
\hline 2011 & 0,139518387 & 0,048999405 & 0.059861229 & 0.080147346 \\
\hline 2012 & 0,131032508 & 0,048579678 & 0.065925338 & 0.076446787 \\
\hline 2013 & 0,128821815 & 0,046823606 & 0.066535494 & 0.03987916 \\
\hline 2014 & 0,121722591 & 0,045149018 & 0.062520234 & 0.038565994 \\
\hline 2015 & 0,128551074 & 0,048847657 & 0.072984321 & 0.043601132 \\
\hline 2016 & 0,129850499 & 0,049687171 & 0.076957651 & 0.041623368 \\
\hline 2017 & 0,14458984 & 0,048320279 & 0.072777387 & 0.037952184 \\
\hline
\end{tabular}

Source : WITS 2017

Herfindahl index for exports of textiles and apparel Indonesia, China and India and the World from 2010 Until 2017 shows the market structure in the form of Perfect competition

Table.2 Trade Specialization Ratio (Indonesia, China, India)

\begin{tabular}{ccccccc}
\hline Year & $\begin{array}{c}\text { TSR } \\
\text { Indonesia }\end{array}$ & Information & $\begin{array}{c}\text { TSR } \\
\text { China }\end{array}$ & Information & $\begin{array}{c}\text { TSR } \\
\text { India }\end{array}$ & Information \\
\hline 2010 & $-0,98114$ & Introduction & 0,741806 & Export Promotion & 0,747806 & Export Promotion \\
\hline 2011 & 0,215144 & Export Promotion & 0,729708 & Export Promotion & 0,742397 & Export Promotion \\
\hline 2012 & 0,207039 & Export Promotion & 0,715183 & Export Promotion & 0,727702 & Export Promotion \\
\hline 2013 & 0,197246 & Export Promotion & 0,742912 & Export Promotion & 0,762706 & Export Promotion \\
\hline 2014 & 0,194874 & Export Promotion & 0,777504 & Export Promotion & 0,736735 & Export Promotion \\
\hline 2015 & 0,210215 & Export Promotion & $-0,08415$ & Introduction & 0,727757 & Export Promotion \\
\hline 2016 & 0,182486 & Export Promotion & 0,798535 & Export Promotion & 0,707013 & Export Promotion \\
\hline 2017 & 0,207032 & Export Promotion & 0,784369 & Export Promotion & 0,698591 & Export Promotion \\
\hline
\end{tabular}
Source : WITS 2017

The results of data processing using the Trade Specialization Ratio (TSR) method, textile exports and apparel become India are more stable compared to Indonesia (2010, Introduction) and China (2015, introduction), but in general the pattern of trade development and stages of textile industrialization and apparel in three countries for the year 2010 to 2017 shows export promotion

Table.3 Revealed Comparative Advantage (Indonesia, China, India)

\begin{tabular}{ccccccc}
\hline Year & $\begin{array}{c}\text { RCA } \\
\text { Indonesia }\end{array}$ & $\begin{array}{c}\text { Index } \\
\text { RCA }\end{array}$ & $\begin{array}{c}\text { RCA } \\
\text { China }\end{array}$ & $\begin{array}{c}\text { Index } \\
\text { RCA }\end{array}$ & $\begin{array}{l}\text { RCA } \\
\text { India }\end{array}$ & Index RCA \\
\hline 2010 & 1,704304 & - & 30,43762 & - & 2,962244 & - \\
\hline
\end{tabular}




\begin{tabular}{rrrrrrr}
\hline 2011 & 1,580002 & 0,072934189 & 3,084651 & 0,898656625 & 2,694951 & 0,090233261 \\
\hline 2012 & 1,637461 & 0,036365946 & 3,015184 & 0,022520203 & 2,833242 & 0,051314809 \\
\hline 2013 & 5,027081 & 2,070046792 & 9,008224 & 1,987619676 & 8,671101 & 2,060487448 \\
\hline 2014 & 1,774377 & 0,647036298 & 3,017295 & 0,665051102 & 2,986467 & 0,655583844 \\
\hline 2015 & 1,82086 & 0,026196546 & 0,269459 & 0,910695042 & 3,14878 & 0,054349277 \\
\hline 2016 & 1,90233 & 0,044742684 & 2,812026 & 9,435808 & 3,169353 & 0,006533787 \\
\hline 2017 & 3,545632 & 0,863836489 & 5,441882 & 0,935217206 & 6,050606 & 0,909098256 \\
\hline Source : WITS 2017 & & & & &
\end{tabular}

Indonesia and India have a stable Revealed Comparative Advantage (RCA) value, but when viewed from the size of the RCA, then China has a comparative advantage and has strong competitiveness in textile and apparel products, even though in 2015 the competitiveness of Chinese textiles and apparel is weak. In order for the RCA to be a dynamic measurement tool for knowing the strengths or weaknesses of excellence and competitiveness, it is necessary to include two elements of time. In this research the time approach was taken by including the RCA Index. Judging from the RCA index, Indonesia and India have the advantages and competitiveness of textiles and apparel in 2013, while China excellence and competitiveness of textiles \& apparel in 2013 and 2016. In general, the results of research on Indonesia, China and India, countries China has a strong competitiveness in the textile and apparel industry compared to Indonesia and India.

Table.4 Constant Market Share (Indonesia, China, India)

\begin{tabular}{cccc} 
Year & $\begin{array}{c}\text { CMS } \\
\text { Indonesia }\end{array}$ & $\begin{array}{c}\text { CMS } \\
\text { China }\end{array}$ & $\begin{array}{c}\text { CMS } \\
\text { India }\end{array}$ \\
\hline 2010 & - & - & - \\
\hline 2011 & 2034399,89 & 41005284,7 & 6246326,14 \\
\hline 2012 & $-810977,65$ & 5554591,1 & $-691157,57$ \\
\hline 2013 & 240453,53 & 27916106 & 7508507,68 \\
\hline 2014 & 76288,11 & 13635095 & 1593774,94 \\
\hline 2015 & $-490730,78$ & 260298657,4 & 1435955,06 \\
\hline 2016 & $-419145,42$ & 225945555,1 & 1732467,69 \\
\hline 2017 & 705104,23 & 4106787,4 & 1791627,25 \\
\hline Source : WITS 2017 & &
\end{tabular}

The calculation of Constant Market Share obtained results, the effect of the growth of textiles and apparel into the world and increase in the effect of the competitiveness of the textile industry and apparel contributed to the general increase in similar industries in China followed by an increase in Indonesia and India.

\section{CONCLUSION AND SUGESTION}

Herfindahl index calculation shows the market structure of Indonesia, China and India in the form of perfect competition. Whereas the approach to Trade Specialization Ratio of Indian exports is more stable than Indonesia and China. The TSR approach generally shows Export Promotion. The Revealed Comparative Adventage approach, Indonesia and India showed stable and stagnant results, when viewed as a whole the amount of RCA, China has a comparative advantage and strong competitiveness. followed by Indonesia and India. 


\section{REFERENCES}

Alam, S. (2018). The trade integration and Pakistan's export performance: Evidence from exporter dynamic database. International Journal of Development Issues, 17(3), 326345. https://doi.org/10.1108/IJDI-04-2018-0058

Amador, J., \& Cabral, S. (2008). The portuguese export performance in perspective: A constant market share analysis. Economic Bulletin and Financial Stability Report, 201221. http://www.bportugal.pt/en-US/BdP Publications Research/AB200813_e.pdf

Guan, Z., Xu, Y., Jiang, H., \& Jiang, G. (2019). International competitiveness of Chinese textile and clothing industry - a diamond model approach. Journal of Chinese Economic and Foreign Trade Studies, 12(1), 2-19. https://doi.org/10.1108/JCEFTS-01-2018-0003

Jayawickrama, A., \& Thangavelu, S. M. (2010). Trade linkages between China, India and Singapore: Changing comparative advantage of industrial products. Journal of Economic Studies, 37(3), 248-266. https://doi.org/10.1108/01443581011061267

Kathuria, L. M. (2013). Analyzing competitiveness of clothing export sector of india and Bangladesh: Dynamic revealed comparative advantage approach. Competitiveness Review, 23(2), 131-157. https://doi.org/10.1108/10595421311305343

Kathuria, L. M. (2018). Comparative advantages in clothing exports: India faces threat from competing nations. Competitiveness Review, 28(5), 518-540. https://doi.org/10.1108/CR-01-2017-0010

Kilduff, P., \& Chi, T. (2007). Analysis of comparative advantage in the textile complex: A study of Eastern European and former Soviet Union nations. Journal of Fashion Marketing and Management, 11(1), 82-105. https://doi.org/10.1108/13612020710734427

Lieberman, E. S. (2005). for Comparative Research APPROACH. 99(3), 435-452.

Mahajan, V. (2019). Structural changes and trade competitiveness in the Indian pharmaceutical industry in product patent regime. International Journal of Pharmaceutical and Healthcare Marketing, 13(1), 21-39. https://doi.org/10.1108/IJPHM-12-2016-0066

Maryam, J., Banday, U. J., \& Mittal, A. (2018). Trade intensity and revealed comparative advantage: an analysis of Intra-BRICS trade. International Journal of Emerging Markets, 13(5), 1182-1195. https://doi.org/10.1108/IJoEM-09-2017-0365

Mcauliffe, R. E. (2014). ). In its treatment, the market shares are expressed as percentages by the Department of Justice. Martin (2010) provides a useful overview of the HHI. 2014.

Nordås, H. K., \& Geneva, C.--. (n.d.). The Global Textile and Clothing Industry post the.

Saki, Z., Moore, M., Kandilov, I., Rothenberg, L., \& Godfrey, A. B. (2019). Revealed comparative advantage for US textiles and apparel. Competitiveness Review, 29(4), 462478. https://doi.org/10.1108/CR-03-2018-0025

Suwannarat, P. (2017). Ascertaining the competitiveness of Thai exports to PRC. 27(3), 275299. https://doi.org/10.1108/CR-04-2016-0026 